\title{
ANTIOXIDANT AND ANTI-INFLAMMATORY PROPERTIES OF A SERIES OF NEW 7,8-DISUBSTITUTED THEOPHYLLINE CONTAINING A PYRAZOLE RING
}

\author{
DMYTRO KOROBKO ${ }^{1}$, DIMITRA J. HADJIPAVLOU-LITINA ${ }^{2}$, LILIYA LOGOYDA ${ }^{1}$ \\ ${ }^{1}$ Department of Pharmaceutical Chemistry, Pharmaceutical Faculty, I. HorbachevskyTernopil State Medical University, Ternopil City, \\ Ukraine. ${ }^{2}$ Department of Pharmaceutical Chemistry, School of Pharmacy, Aristotle University of Thessaloniki, Thessaloniki, Greece. \\ Email: Logojda@tdmu.edu.ua
}

Received: 16 March 2018, Revised and Accepted: 14 April 2018

ABSTRACT

Objective: The objective of this study was to synthesize methyl 1-(1,3-dimethyl-2,6-dioxo-7-arylalkyl-(alkenyl-)-2,3,6,7-tetrahydro-1H-purin-8-yl)5-(4-methyl-(methoxy-, chloro-)phenyl)-1H-pyrazole-3-carboxylates and studying their antioxidant and anti-inflammatory properties by in vitro methods.

Methods: New derivatives of 1,3-dimethylxanthine with pyrazole at position 8 were synthesized by the interaction of 8-bromotheophylline with arylalkyl-(alkenyl) halides, hydrazine hydrate, and methyl 4-(4-R)-2,4-dioxobutanoate. For most obtained compounds, antioxidant activity (by 2,2-diphenyl-1-picrylhydrazyl and 2,2'-azobis(2-amidinopropane) dihydrochloride) and anti-inflammatory (by Soybean LOX inhibition) activity was investigated.

Result: The most effect on free radical oxidation processes was recorded for substances with a phenylalyl radical at position 7 of the molecules (10, 13, and 16). In the activity of inhibition of peroxidation of lipids (89-92\%), they predominate Trolox (88\%). Their IC50 indices for LOX inhibition are $15.0,17.5$, and $27.5 \mu \mathrm{M}$, respectively, but less than the nordihydroguaretic acid reference compound used.

Conclusion: The antioxidant and anti-inflammatory properties of a series of synthesized 7,8-disubstituted theophylline containing the pyrazole cycle have been studied using modern in vitro research methods. The prospect of conducting further synthetic and pharmacological studies for compounds with phenylalyl radical in the 7 positions of their molecules is shown.

Keywords: Methyl 1-(1,3-dimethyl-2,6-dioxo-7-arylalkyl-(alkenyl-)-2,3,6,7-tetrahydro-1H-purin-8-yl)-5-(4-methyl-(methoxy-, chloro-)phenyl)-1Hpyrazole-3-carboxylates, Active forms of Oxygen, Lipoxygenase, Antioxidant and anti-inflammatory activities.

(c) 2018 The Authors. Published by Innovare Academic Sciences Pvt Ltd. This is an open access article under the CC BY license (http://creativecommons. org/licenses/by/4. 0/) DOI: http://dx.doi.org/10.22159/ajpcr.2018.v11i6.25990

\section{INTRODUCTION}

Active forms of oxygen (AFO), which play an important role in many physiological and biochemical processes are constantly generated in the body as a result of aerobic metabolism. Under normal conditions of existence AFOs do not accumulate in cells, but under the influence of extreme factors of different genesis (chemical pollution, ionizing radiation, hypoxia, toxic substances, inflammatory processes, etc.) their formation is intensified, which leads to increased peroxidation of lipids, oxidative modification of proteins, destruction of nucleic acids, and carbohydrates and can cause structural and metabolic disorders in the cells [1]. To correct such phenomena, antioxidants (compounds of various origin that are capable of removing or inhibiting free radical oxidation of organic substances with monomolecular Oxygen) are used.

It is well-known that theophylline, as a representative of methylxanthines, exhibits a wide range of biological activity [2]. However, the chemical modification of its molecule in position 7 is accompanied by the production of compounds with a narrower profile of pharmacological action against the background of reducing the number of side effects and low toxicity [3]. Various derivatives of pyrazole are also promising research objects since among them are identified monoamine oxidase and cyclooxygenase- 2 inhibitors, substances with hepatoprotective, anti-inflammatory, analgesic, antioxidant, antimicrobial, anti-tuberculosis, and antitumor activities [4-6]. Thus, it seemed to us appropriate to combine in the same molecule two abovementioned heterocycles, which could lead to the obtainment of target products with a higher potential for biological activity

\section{METHODS}

\section{Experimental}

All starting materials and solvents were obtained from commercial sources and used without further purification. Azobis (2-amidinopropane) dihydrochloride (AAPH), 2,2-diphenyl-1picrylhydrazyl (DPPH), nordihydroguaretic acid (NDGA), and Trolox were purchased from the Aldrich Chemical Co. (Milwaukee, WI). Soybean LOX, linoleic acid sodium salt was obtained from Sigma Chemical Co. (St. Louis, MO). For the in vitro tests, an ultraviolet (UV)-1700 PharmaSpec Shimadzu UV-visible double beam spectrophotometer was used.

\section{Biological experiments}

General methods

Each in vitro experiment was performed at least in triplicate, and the standard deviation of absorbance was $<10 \%$ of the mean.

\section{In vitro assays}

Determination of the reducing activity of the stable radical DPPH To a solution of DPPH in absolute ethanol an equal volume of the compounds dissolved in DMSO was added. A stock solution $(10 \mathrm{mM})$ of the compounds was used. The concentrations of the final solutions of the compounds were $100 \mu \mathrm{M}$. After 20 and $60 \mathrm{~min}$ at room temperature, the absorbance was recorded [7].

\section{Inhibition of linoleic acid peroxidation}

Production of conjugated diene hydroperoxide by oxidation of sodium linoleate in an aqueous dispersion was monitored at $234 \mathrm{~nm}$ [8]. AAPH 
is used as a free radical initiator. $10 \mu \mathrm{l}$ of the $16 \mathrm{mM}$ sodium linoleate solution was added to the UV cuvette containing $0.93 \mathrm{~mL}$ of $0.05 \mathrm{M}$ phosphate buffer, $\mathrm{pH} 7.4$ prethermostated at $37^{\circ} \mathrm{C}$. The oxidation reaction was initiated at $37^{\circ} \mathrm{C}$ under air by the addition of $50 \mu \mathrm{L}$ of $40 \mathrm{mM}$ AAPH solution. Oxidation was carried out in the presence of aliquots $(10 \mu \mathrm{L})$ in the assay without antioxidant. Lipid oxidation was measured in the presence of the same level of DMSO. The rate of oxidation at $37^{\circ} \mathrm{C}$ was monitored by recording the increase in absorption at $234 \mathrm{~nm}$ caused by conjugated diene hydroperoxides and compared with the appropriate standard Trolox.

\section{Soybean LOX inhibition study in vitro}

In vitro study was evaluated as reported previously [7]. The tested compounds dissolved in DMSO were incubated at room temperature with sodium linoleate $(100 \mu \mathrm{M})$ and $0.2 \mathrm{~mL}$ of enzyme solution $\left(1 / 9 \times 10^{-4} \mathrm{w} / \mathrm{v}\right.$ in saline). The conversion of sodium linoleate to 13-hydroperoxylinoleic acid at $234 \mathrm{~nm}$ was recorded and compared with the appropriate standard inhibitor (NDGA). Several concentrations were used for the determination of $\mathrm{IC}_{50}$ values.

\section{RESULTS AND DISCUSSION}

Performed synthetic transformations to obtain the test compounds 8-16 are shown in Scheme 1.

Conditions of conducting reactions (number of reacting components of mixtures, temperature regime, and duration of chemical processes), peculiarities of their flow and discussion of the results of spectral studies for methyl 1-(1,3-dimethyl-2,6-dioxo-7-arylalkyl-(alkenyl-)-2,3,6,7tetrahydro-1H-purin-8-yl)-5-(4-methyl-(methoxy-, chloro-)phenyl)$1 H$-pyrazole-3-carboxylates described earlier [9]. The structure of the target products and individual constants are presented in Table 1.

Among the existing methods for evaluating antioxidant activity, we have chosen an approach based on the interaction of test substances with di(phenyl)-(2,4,6-trinitrophenyl)iminoazanium, a substance that is more commonly known as DPPH. The said compound is a stable free radical, the alcoholic solutions of which are stained in intense purple $\left(\lambda_{\max }=517 \mathrm{~nm}\right)$. When DPPH interacts with substances that capable of binding to free radicals, produce products that are mostly colored in shades of yellow and do not absorb light at the above wavelength. This method is fast, easy to implement and allows for the screening of large arrays of investigated substances $[10,11]$.

We also used the method of antiradical action determination for 7,8-disubstituted theophylline using AAPH, since the activity of the peroxyl radicals that arise under the action of the latter has a greater similarity to the development of peroxide processes oxidation of lipids in cells [8].

As is known, lipoxygenase catalyzed the first two stages of the metabolism of the acid of arachidonate to leukotrienes, important mediators of inflammation [12]. Based on the features of the structures of the synthesized compounds and to find new substances with antiinflammatory action, it seemed to us expedient to investigate this

Table 1: Physical and chemical characteristics of the new 7.8-disubstituted theophylline

\begin{tabular}{|c|c|c|c|c|c|}
\hline \multicolumn{6}{|c|}{$8-16$} \\
\hline $\begin{array}{l}\text { Number of } \\
\text { compounds }\end{array}$ & $\mathbf{R}$ & $\mathbf{R}_{1}$ & Yield, \% & T. Pl., ${ }^{\circ} \mathrm{C}$ & $\begin{array}{l}\text { Empirical } \\
\text { Formula }\end{array}$ \\
\hline 8 & $\mathrm{CH}_{2}-\mathrm{C}_{6} \mathrm{H}_{5}$ & $\mathrm{CH}_{3}$ & 93,2 & 197-199 & $\mathrm{C}_{27} \mathrm{H}_{26} \mathrm{~N}_{6} \mathrm{O}_{4}$ \\
\hline 9 & $\mathrm{CH}_{2}^{2}-\mathrm{CH}_{2}-\mathrm{C}_{6} \mathrm{H}_{5}$ & $\mathrm{CH}_{3}^{3}$ & 95,4 & 168-170 & $\mathrm{C}_{28}^{26} \mathrm{H}_{28}^{20} \mathrm{~N}_{6} \mathrm{O}_{4}^{4}$ \\
\hline 10 & $\mathrm{CH}=\mathrm{CH}^{2} \mathrm{C}_{6} \mathrm{H}_{5}{ }_{5}^{3}$ & $\mathrm{CH}_{3}^{3}$ & 90,7 & $157-159$ & $\mathrm{C}_{28}^{28} \mathrm{H}_{26}^{28} \mathrm{~N}_{6}^{6} \mathrm{O}_{4}^{4}$ \\
\hline 11 & $\mathrm{CH}_{2}-\mathrm{C}_{6} \mathrm{H}_{5}{ }^{\circ}$ & $\mathrm{OCH}_{3}^{3}$ & 77,7 & $184-186$ & $\mathrm{C}_{27}^{28} \mathrm{H}_{26}^{26} \mathrm{~N}_{6} \mathrm{O}_{5}^{4}$ \\
\hline 12 & $\mathrm{CH}_{2}^{2}-\mathrm{CH}_{2}^{5}-\mathrm{C}_{6} \mathrm{H}_{5}$ & $\mathrm{OCH}_{3}^{3}$ & 91,6 & 149-151 & $\mathrm{C}_{28} \mathrm{H} 28 \mathrm{~N}^{26} \mathrm{O}_{5}$ \\
\hline 13 & $\mathrm{CH}=\mathrm{CH}-\mathrm{C}_{6} \mathrm{H}_{5}{ }^{3}$ & $\mathrm{OCH}_{3}^{3}$ & 86,9 & $95-97$ & $\mathrm{C}_{28}^{28} \mathrm{H} 26 \mathrm{~N}_{6} \mathrm{O}_{5}{ }_{5}^{3}$ \\
\hline 14 & $\mathrm{CH}_{2}-\mathrm{C}_{6} \mathrm{H}_{5}{ }^{\circ}$ & $\mathrm{Cl}$ & 87,0 & $157-159$ & $\mathrm{C}_{26}^{28} \mathrm{H}_{23} \mathrm{ClN}_{6} \mathrm{O}_{4}^{3}$ \\
\hline 15 & $\mathrm{CH}_{2}^{2}-\mathrm{CH}_{2}^{6}-\mathrm{C}_{6} \mathrm{H}_{5}$ & $\mathrm{Cl}$ & 94,2 & $166-168$ & $\mathrm{C}_{22}^{26} \mathrm{H}_{25}^{23} \mathrm{ClN}_{6}^{6} \mathrm{O}_{4}^{4}$ \\
\hline 16 & $\mathrm{CH}=\mathrm{CH}-\mathrm{C}_{6} \mathrm{H}_{5}$ & $\mathrm{Cl}$ & 93,1 & $167-169$ & $\mathrm{C}_{27} \mathrm{H}_{23} \mathrm{ClN}_{6} \mathrm{O}_{4}$ \\
\hline
\end{tabular}

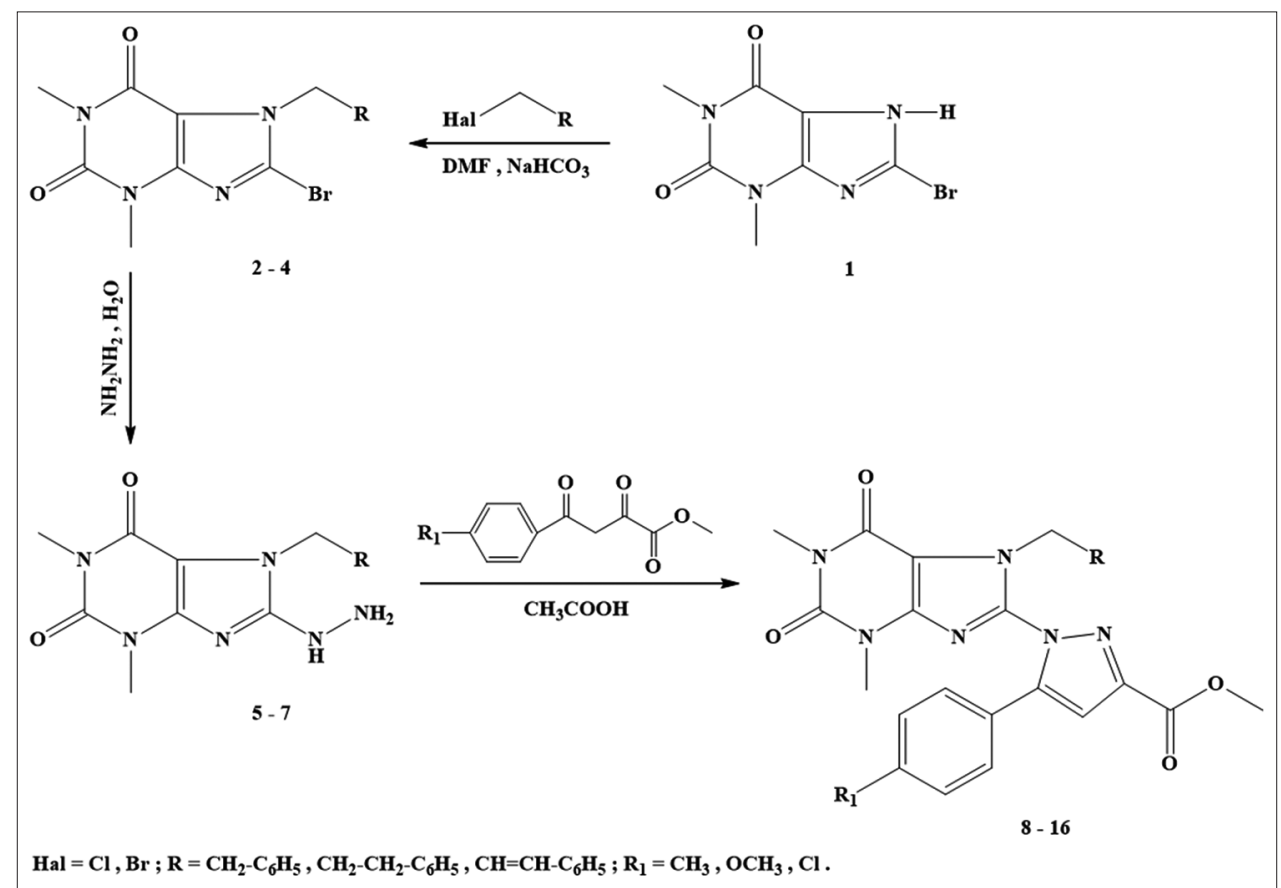

Scheme 1: Synthesis of new 7.8-disubstituted theophylline with a pyrazole fragment 
Table 2: Indicators of antioxidant and anti-inflammatory activity synthesized 7,8-disubstituted theophylline

\begin{tabular}{|c|c|c|c|c|}
\hline No of compounds & $\begin{array}{l}\text { Reducing activity, } \\
\% 100 \mu \mathrm{M} 20 \mathrm{~min}\end{array}$ & $\begin{array}{l}\text { Reducing activity, } \\
\% 100 \mu \mathrm{M} 60 \mathrm{~min}\end{array}$ & $\begin{array}{l}\text { Anti-lipid peroxidation, } \\
\% \text { at } 100 \mu \mathrm{M}\end{array}$ & $\begin{array}{l}\mathrm{IC}_{50} \text { or \% LOX } \\
\text { inhibition at } 100 \mu \mathrm{M}\end{array}$ \\
\hline 8 & 25.0 & No & 37.0 & $23.0 \%$ \\
\hline 9 & No & 10.0 & 66.0 & No \\
\hline 10 & No & 4.0 & 92.0 & $17.5 \mu \mathrm{M}$ \\
\hline 11 & 8.0 & No & 54.0 & $36.0 \%$ \\
\hline 12 & No & No & 90.0 & $55.0 \mu \mathrm{M}$ \\
\hline 13 & No & No & 90.0 & $15.0 \mu \mathrm{M}$ \\
\hline 15 & No & No & 47.0 & $37.5 \mu \mathrm{M}$ \\
\hline 16 & No & No & 89.0 & $27.5 \mu \mathrm{M}$ \\
\hline NDGA & 93.0 & 97.0 & & $0.55 \mu \mathrm{M}$ \\
\hline Trolox & & & 88.0 & \\
\hline
\end{tabular}

No activity under the reported experimental conditions

activity on the in vitro model of inhibition of Soybean lipoxygenase (LOX).

The results of the performed studies are presented in Table 2 .

By value and reducing activity, all detectable substances are significantly inferior to NDGA. In addition, compounds $12,13,15$, and 16 for both $20 \mathrm{~min}$ and $60 \mathrm{~min}$ of this type of biological action were not detected.

The results of determining the percentage of inhibition of lipid peroxidation are much more interesting. Thus, the minimum activity is set for substance $8(37 \%)$, and maximum - for $10(92 \%)$. The data in Table 2 indicate the highest degree of antioxidant protection of theophylline derivatives with the phenylalyl substituent at position 7 of the molecules $(10,13$, and 16). An interesting one the fact that the substitution of the methyl group in the 4 position of the aromatic substituent of the pyrazole residue on $\mathrm{Hal}(\mathrm{Cl})$ by $40 \%$ reduces the activity of the phenylpropyl derivative ( 9 and 15, respectively) and practically does not affect the antioxidant effect of the phenylalyl (10 and 16 , respectively). Introduction of the 4-position of the aromatic component of the pyrazole ring of the methoxy group leads to a significant increase in the percentage of inhibition of lipid peroxidation for phenethyl11 and phenylpropyl12 derivatives $(46 \%$ and $36 \%$, respectively). Antiradical activity of phenylalyl derivative 13 remains at $90 \%$. In general, the following should be noted: The highest antioxidant effect was observed for 1-(1,3-dimethyl-2,6-dioxo-7-arylalkyl-(alkenyl)-2,3,6,7-tetrahydro-1 H-purine-8-yl)-5-(4-methoxyphenyl)- $1 \mathrm{H}$ pyrazole-3-carboxylates (11-13), which is consistent with the literature data [13]

The values of LOX inhibition rates are completely correlated with the above SAR analysis for inhibition of 7,8-disubstituted theophylline of lipid peroxide oxidation. The greatest efficiency was observed for compounds with a phenylalyl radical at position 7 of the molecules $(10$, 13 , and 16$)$. Their $\mathrm{IC}_{50 \mathrm{~s}}$ are within the range of $15.0-27.5 \mu \mathrm{M}$, but inferior to the reference NDGA $\left(\mathrm{IC}_{50}=0.55 \mu \mathrm{M}\right)$. Results obtained confirmed the thesis that it is antioxidants (free radical traps) that exhibit antiinflammatory properties and cause inhibition of LOX.

\section{CONCLUSION}

The antioxidant and anti-inflammatory properties of a series of synthesized 7,8-disubstituted theophylline containing the pyrazole cycle have been studied using modern in vitro research methods. The presence of these types of pharmacological action in tested compounds is shown, and the effectiveness of inhibition of lipid peroxidation oxidation of 4 substances is dominated by Trolox. Research in this direction is ongoing.

\section{AUTHOR'S CONTRIBUTION}

DmytroKorobko, Liliya Logoyda conceived and designed the experiments. DmytroKorobko performed an experimental synthetic part. Dimitra J. Hadjipavlou-Litinaper formed pharmacological research. DmytroKorobko, Liliya Logoyda worked together on the development of the ideas presented in this paper and contributed to the data analysis and manuscript writing.

\section{CONFLICTS OF INTEREST}

The authors have none to declared.

\section{REFERENCES}

1. Roberfroid M, Colderon PB. Free Radicals and Oxidation Phenomena in Biological Systems. Brussels, New York: University Catholique de Louvain; 1995.

2. Wilson CO, Gisvold O, Beale JM Jr. In: Beale JM Jr, Block JH, editors. Wilson and Gisvold's Textbook of Organic Medicinal and Pharmaceutical Chemistry. 12 $2^{\text {th }}$ ed. Hong Kong: Lippincott Williams and Wilkins, A Wolters Kluwer Business; 2011.

3. Kleeman A, Engel J, Kutscher B, Reichert D. In Pharmaceutical Substances. $3^{\text {rd }}$ ed. Stuttgart: Thieme; 1999.

4. Ansari A, Ali A, Asif M, Shamsuzzaman S. Review: Biologically active pyrazole derivatives. New J Chem 2017;41:16-41.

5. Naim MJ, Alam O, Nawaz F, Alam J, Alam P. Current status of pyrazole and its biological activities. J Pharm Bioallied Sci 2016;8:2-17.

6. Shaikh SI, Zaheer Z, Mokale SN, Lokwani DK. Development of new pyrazolehybrids as antitubercular agents: Synthesis, biological evaluation and moleculardocking study. Int $\mathrm{J}$ Pharm Pharm Sci 2017;9:50-6.

7. Pontiki E, Hadjipavlou-Litina DD. Synthesis and pharmacochemical evaluation of novel aryl-acetic acid inhibitors of lipoxygenase, antioxidants, and anti-inflammatory agents. Bioorg Med Chem 2007; 15:5819-27.

8. Lie'geois C, Lermusieau G, Collins SJ. Reducing powers of various hop varieties. Agric Food Chem 2000;48:1129-34.

9. Korobko D. Synthesis of the row of new functional derivatives of 7-arylalkyl-8-hydrazine theophyllines, Science Rise. Pharm Sci 2016;3/4:39-45.

10. Koleva II, Van Beek TA, Linssen JPH, de Groot A, Evstatieva LN. Screening of plant extracts for antioxidant activity: A comparative study on three testing methods, Phytochem Anal 2001;13:8-17.

11. Meziti A, Bouriche H, Hichem M, Kadaa S, Abderrahmane S. Antioxidant and anti-inflammatory activities of Rubus fruticosus and Zizyphus vulgarismethanol extracts. Int J Pharm Pharm Sci 2017;9:69-76.

12. Crooks SW, Stockley RA. Leukotriene B4. Int J Biochem Cell Biol 1998;30:173-8.

13. Selvam C, Jachak SM, Thilagavathi R, Chakraborti AK. Design, synthesis, biological evaluation and molecular docking of curcumin analogues as antioxidant, cyclooxygenase inhibitory and antiinflammatory agents. Bioorg Med Chem Lett 2005;15:1793-7. 